\title{
Gorontalo
}

Journal of Public Health

Volume 3 - No. 1 - April 2020

P-ISSN: 2614-5057, E-ISSN: 2614-5065

\section{Hubungan Kebiasaan Cuci Tangan, Mengelola Air Minum dan Makanan dengan Stunting di Sulawesi Tengah}

\author{
Relationship between Handwashing, Treating Drinking \\ Water and Food with Stunting in Central Sulawesi
}

\author{
Dedi Mahyudin Syam*, Herlina S.Sunuh \\ Jurusan Sanitasi, Politeknik Kesehatan Kemenkes Palu \\ Palu, Indonesia \\ *email: dmahyudin21@gmail.com
}

\begin{abstract}
Environmental factors, birth weight and food intake can influence the incidence of stunting. The prevalence of stunting in toddlers in Central Sulawesi Province in 2015 was very short by $11.4 \%$ and short by 23.9\%. 2-16 very short categories by $10.2 \%$ and short categories by $21.8 \% .2017$ the very short category was $14.0 \%$ and the short category was 22.1\%. The purpose of this research was to know handwashing with soap, treating drinking water and food related to stunting in Central Sulawesi. The type of research was analytic with the approach of cross sectional survey with a sample 289 people in 4 (four) Regency Areas (Banggai, Donggala, Sigi and Palu). Data processing and analysis include univariate and bivariate were used chi square test. Results of 289 respondents carry out handwasing with soap 176 (60.9\%), not carry out handwasing with soap activity $113(39.1 \%)$, statistical test obtained $p$ value $=0.000$. Treating drinking water and food 270 (93.4\%), not treating clean water and food only 19 (6.6\%), stunting status 133 (46.0\%), not stunting 155 (56.0\%), statistical test obtained $p$ value $=0.001$. Conclusion There was a relationship between hand washing with soap, treating drinking water and food with stunting in Central Sulawesi.
\end{abstract}

Keywords: washing hands; drinking water and food; stunting

\begin{abstract}
Abstrak
Faktor lingkungan, berat badan lahir dan asupan makanan dapat mempengaruhi kejadian stunting. Prevalensi stunting pada balita di Provinsi Sulawesi Tengah tahun 2015 kategori sangat pendek sebesar $11.4 \%$ dan pendek sebesar 23.9\%. 216 kategori sangat pendek sebesar $10.2 \%$ dan kategori pendek sebesar $21,8 \%$. 2017 kategori sangat pendek sebesar $14.0 \%$ dan kategori pendek sebesar $22.1 \%$. Tujuan penelitian adalah diketahuinya cuci tangan pakai sabun (CTPS), mengelola air minum dan makanan berhubungan dengan stunting di Sulawesi Tengah. Jenis penelitian adalah analitik dengan pendekatan cross sectional survey dengan sampel berjumlah 289 orang di 4 (empat) daerah Kabupaten (Banggai, Donggala, Sigi dan Palu). Pengolahan dan analisis data meliputi univariat, Bivariat menggunakan uji chi square. Hasil penelitian menunjukkan dari 289 responden melaksanakan CTPS 176 (60,.9\%), tidak CTPS 113 (39,1\%), Uji statistik diperoleh nilai $p=0,000$. Sudah mengelola air minum dan makanan $270(93,4 \%)$, tidak mengelola air bersih dan makanan $19(6,6 \%)$, status gizi stunting $133(46,0 \%)$, tidak stunting $155(56,0 \%)$, uji statistik diperoleh nilai $p=$ 0,001 . Kesimpulan ada hubungan cuci tangan pakai sabun, pengelolaan air minum dan makanan dengan stunting di Sulawesi Tengah.
\end{abstract}

Kata kunci: cuci tangan; air minum dan makanan; stunting 


\section{PENDAHULUAN}

Sanitasi merupakan salah satu aspek penting dalam menunjang kesejahteraan masyarakat, hal ini disebabkan karena sanitasi berhubungan secara langsung dengan masalah kesehatan, pola hidup masyarakat, kondisi lingkungan pemukiman, dan kenyamanan dalam kehidupan sehari - hari. Penyediaan sumber air bersih ataupun air minum yang layak dan berkelanjutan merupakan salah satu bagian dari upaya penggalakan sanitasi. Air minum merupakan kebutuhan paling penting dalam kehidupan manusia. Hal ini karena tubuh manusia sebagian besarnya adalah cairan dan pemenuhan kebutuhan hidrasi pada tubuh menjadi hal yang krusial untuk tetap membiarkan tubuh menjalankan fungsi - fungsinya dengan baik. Kondisi ketersediaan air minum layak di Indonesia dapat dikatakan cukup baik, didukung dengan melihat persentase rumah tangga yang memiliki akses terhadap layanan sumber air minum yang layak dan berkelanjutan baik secara nasional maupun untuk daerah perkotaan dan pedesaaan mengalami peningkatan di dua tahun terakhir. Presentase rumah tangga yang memiliki akses terhadap layanan sumber air minim layak dan berkelanjutan tahun 2015 perkotaan $72,11 \%$, pedesaan $55,30 \%$, tahun 2016 perkotaan $71,29 \%$, pedesaan $55,65 \%$, tahun 2017 perkotaan $71,42 \%$ dan pedesaan $57,29 \%$ (BPS, 2018). Menurut Harriet et al (2016)dalam penelitiannya bahwa faktor sanitasi dan pengolahan air merupakan faktor risiko terhadap kejadian stunting pada tiga wilayah yakni Sikka Nusa Tenggara timur, Jayawijaya Papua dan Klaten Jawa Tengah.

Stunting menggambarkan status gizi kurang yang bersifat kronis pada masa pertumbuhan dan perkembangan sejak awal kehidupan. Keadaan ini dipresentasikan dengan nilai $z$-score tinggi badan menurut umur (TB/U) kurang dari -2 standar deviasi (SD) berdasarkan standar pertumbuhan menurut WHO. Secara global, sekitar 1 sampai 4 balita mengalami stunting. Maslah gizi terutama stunting pada balita dapat menghambat perkembangan anak, dengan dampak negatif yang akan berlangsung dalam kehidupan selanjutnya penurunan intelektual, rentan terhadap penyakit tidak menular, penurunan produktivitas hingga menyebabkan kemiskinan dan risiko melahirkan bayi dengan Berat Lahir Rendah (WHO, UNICEF, USAID, 2015).

Prevalensi stunting pada balita di Provinsi Sulawesi Tengah tahun 2015 untuk kategori sangat pendek sebesar 11,4\% dan kategori pendek sebesar 23,9\% (35,3\%), tahun 2016 untuk kategori sangat pendek sebesar 10,2\% dan kategori pendek sebesar 28,8\% (32,0\%). Tahun 2017 kategori sangat pendek sebesar $14,0 \%$ dan kategori pendek sebesar 22,1\% (36,1\%)(Dirjen Kesmas Kemenkes RI, 2018). Sehingga tujuan dari penelitian ini adalah untuk mengetahui hubungan kebiasaan cuci tangan menggunakan sabun, pengelolaan ari minum dan makanan dengan kejadian stunting di Sulawesi Tengah.

\section{METODE}

Jenis penelitian ini adalah observasional analitik dengan desain cross sectional. Lokasi penelitian adalah wilayah Sulawesi Tengah meliputi 4 (empat) Kabupaten/Kota yaitu Kabupaten Banggai, Kabupaten Donggala, Kabupaten Sigi dan Kota Palu. Waktu penelitian pada bulan Agustus sampai November 2019. Pemilihan lokasi penelitian berdasarkan pertimbangan bahwa daerah tersebut merupakan daerah dengan prevalensi stunting tinggi di Sulawesi Tengah. Populasi dalam penelitian ini adalah seluruh bayi yang berusia $0-23$ bulan. Teknik pengambilan sampel menggunakan cara estimasi proporsional populasi, sampel sebesar 289 orang baduta yang terdiri dari Kabupaten Banggai 87 orang, Donggala 67 orang, Sigi 95 orang dan Palu 44 orang. 
Variabel penelitian meliputi status cuci status gizi baduda, perilaku cuci pakai sabun dan pengelolaan air minum dan makanan. Variabel cuci tangan pakai sabun (CTPS) adalah perilaku responden mencuci tangan menggunakan air bersih dan sabun sebelum dan setelah aktivitas yang kemungkinan tangan terpapar kotoran. Kategori CTPS adalah cuci tangan pakai sabun jika responden mencuci tangan pakai sabun dengan air mengalir sebelum dan setelah melakukan aktivitas yang memungkinkan tangan terpapar kotoran dan kategori tidak CTPS apabila responden tidak mencuci tangan pakai sabun dengan air mengalir. Variabel pengelolaan air minum dan makanan adalah responden mengola, menyimpan dan memanfaatkan air minum dan menggunakan air bersih untuk mengolah makanan. Dikategorikan mengelola air minum dan makanan jika responden mengola, menyimpan dan memanfaatkan air minum dan air bersih untuk mengola makanan dan kategori tidak mengelola jika responden tidak mengola, menyimpan dan memanfaatkan air minum dan air bersih untuk mengola makanan. Teknik pengumpulan data melalui wawancara dengan menggunakan kuisioner terhadap orang tua baduta dan observasi. Pengukuran antropometri meliputi pengukuran berat badan dan panjang badan. Pengukuran berat badan menggunakan timbangan digital, sedangkan panjang badan menggunakan alat ukur length board. Pengukuran antropometri hanya terhadap baduta. Analisis data meliputi univariat digunakan untuk menggambarkan karakteristik responden penelitian, karakteristik subjek penelitian, perilaku cuci tangan pakai sabun, perilaku pengeloaan air minum dan makanan dan prevalensi stunting pada baduta $0-23$ bulan. Bivariat menggunakan uji chi-square dengan derajat kepercayaan 95\% (nilai a $\leq 0,05$ ).

\section{HASIL DAN PEMBAHASAN}

\section{Karakteristik Subjek Penelitian}

Karakteristik responden orang tua baduta di Sulawesi Tengah ditunjukkan pada Tabel 1. Karakteristik orang tua baduta berdasarkan tingkat pendidikan paling banyak adalah SLTA $(39,4 \%)$ sedangkan paling sedikit adalah tingkat Diploma $(1,4 \%)$. Berdasarkan jenis pekerjaan paling banyak sebagai Ibu Rumah Tangga (IRT) $(78,2 \%)$.

Tabel 1. Karakteristik Orang Tua Baduta Subjek Penelitian

\begin{tabular}{lcc}
\hline \multirow{2}{*}{ Karakteristik } & \multicolumn{2}{c}{ Jumlah } \\
\cline { 2 - 3 } & $\mathrm{n}$ & $\%$ \\
\hline Tingkat Pendidikan & & \\
SD & 53 & 18,3 \\
SLTP & 107 & 37,0 \\
SLTA & 114 & 39,4 \\
Diploma & 4 & 1,4 \\
Sarjana & 11 & 3,8 \\
Jenis Pekerjaan & & \\
PNS & 2 & 0,7 \\
Tani & 22 & 7,6 \\
Nelayan & 2 & 0,7 \\
Buruh & 3 & 1,0 \\
Wiraswasta & 25 & 8,7 \\
Sopir & 1 & 0,3 \\
IRT & 226 & 78,2 \\
Honor & 1 & 0,3 \\
\hline Total & 289 & 100 \\
\hline
\end{tabular}


Tabel 2. Karakteristik Baduta 0 - 23 Bulan Subjek Penelitian

\begin{tabular}{lcc}
\hline \multirow{2}{*}{ Karakteristik } & \multicolumn{2}{c}{ Jumlah } \\
\cline { 2 - 3 } & $\mathrm{n}$ & $\%$ \\
\hline Jenis Kelamin & 142 & 49,1 \\
$\quad$ Laki-laki & 147 & 50,9 \\
$\quad$ Perempuan & & \\
Kelompok Umur (Bulan) & 24 & 8,3 \\
$0-5$ & 63 & 21,8 \\
$6-11$ & 202 & 69,9 \\
$12-23$ & 289 & 100 \\
\hline Total &
\end{tabular}

Karakteristik baduta subjek penelitian ditunjukkan pada Tabel 2. Karakteristik jenis kelamin baduta yang terbanyak adalah perempuan yakni 147 $(50,9 \%)$ sedangkan kelompok umur yang terbanyak adalah $12-23$ bulan $(69,9 \%)$.

Tabel 3. Distribusi Responden berdasarkan Perilaku Cuci Tangan, Pengelolaan Air Minum dan Makanan dan Status Gizi Stunting

\begin{tabular}{lcc}
\multirow{2}{*}{ Perilaku Responden } & \multicolumn{2}{c}{ Jumlah } \\
\cline { 2 - 3 } & $\mathrm{n}$ & $\%$ \\
\hline Perilaku Cuci Tangan & 176 & 60,9 \\
$\quad$ CTPS & 113 & 39,1 \\
$\quad$ Tidak CPTS & & \\
Perilaku Pengelolaan Air & & \\
Minum dan Makanan & 270 & 93,4 \\
$\quad$ Mengelola & 19 & 6,6 \\
$\quad$ Tidak Mengelola & & \\
Status Gizi & 133 & 46,0 \\
$\quad$ Stunting & 156 & 54,0 \\
$\quad$ Tidak Stunting & 289 & 100 \\
\hline Total & & \\
\hline
\end{tabular}

Distribusi responden berdasarkan perilaku cuci tangan pakai sabun (CTPS), perilaku pengelolaan air minum dan makanan, dan status gizi subjek penelitian ditunjukkan pada Tabel 3. Perilaku responden tentang cuci tangan lebih banyak yang mencuci tangan pakai sabun $(60,9 \%)$ sedangkan perilaku responden tentang pengelolaan air minum dan makanan lebih banyak yang mengelolah air minum dan makanan $(93,4 \%)$. Status tidak stunting lebih banyak dibandingkan dengan stunting (54,0\%). Responden yang sudah melaksanakan cuci tangan pakai sabun lebih banyak karena tingkat pendidikan paling banyak tamat SMA $(39,4 \%)$, sehingga responden lebih mudah menerima informasi terkait dengan pola hidup sehat baik melalui media elektronik maupun penyuluhan dari tenaga kesehatan.

Hasil penelitian ini sejalan dengan yang dilaksanakan di Kota Sulubussalam Aceh menunjukkan bahwa sebagian besar tingkat pendidikan ibu tergolong pendidikan tinggi yaitu tamat SMA. Ibu dengan tingkat pendidikan tinggi diharapkan memiliki sikap positif terhadap gizi makanan sehingga dapat membantu pemenuhan kebutuhan gizi yang cukup untuk keluarga. Tingkat pendidikan yang tinggi juga mempengaruhi kemampuan dalam menerima informasi mengenai gizi dan kesehatan anak. Beberapa ibu mengemukakan bahwa mereka sering menonton televisi dan membaca surat kabar/majalah, 
dimana dari kedua media informasi tersebut mereka mendapatkan pengetahuan tentang gizi dan kesehatan anak yang baik (Lestari dkk, 2014).

\section{Hubungan Cuci Tangan Pakai Sabun (CTPS) dengan Stunting}

Hasil analisis bivariat antara variabel cuci tangan pakai sabun (CTPS) dengan stunting ditunjukkan pada Tabel 4. Salah satu pilar STBM adalah cuci tangan pakai sabun (CTPS). Hasil penelitian tentang perilaku cuci tangan pakai sabun terhadap stunting menunjukkan bahwa dari 289 responden, yang sudah menerapkan cuci tangan pakai sabun sebanyak 176 orang diantaranya 55 orang $(31,3 \%)$ mengalami stunting dan sebanyak 121 orang $(68,7 \%)$ tidak mengalami stunting. Sedangkan responden yang belum menerapkan perilaku cuci tangan pakai sabun sebanyak 113 responden diantaranya 78 orang $(69,0 \%)$ mengalami stunting dan 35 orang $(31,0 \%)$ tidak mengalami stunting.

Tabel 4. Analisis Bivariat Cuci Tangan Pakai dan Pengelolaan Air Minum dan Makanan dengan Stunting

\begin{tabular}{|c|c|c|c|c|c|c|c|}
\hline \multirow{3}{*}{ Variabel } & \multicolumn{6}{|c|}{ Status gizi } & \multirow{3}{*}{$\begin{array}{c}p \\
\text { value }\end{array}$} \\
\hline & \multicolumn{2}{|c|}{ Stunting } & \multicolumn{2}{|c|}{$\begin{array}{c}\text { Tidak } \\
\text { Stunting }\end{array}$} & \multicolumn{2}{|c|}{ Jumlah } & \\
\hline & $\mathrm{n}$ & $\%$ & $\mathrm{n}$ & $\%$ & $\mathrm{n}$ & $\%$ & \\
\hline \multicolumn{8}{|l|}{ Cuci Tangan Pakai Sabun } \\
\hline Ya & 55 & 31,3 & 121 & 68,7 & 176 & 60,8 & \multirow{2}{*}{0,000} \\
\hline Tidak & 78 & 69,0 & 35 & 31,0 & 113 & 39,2 & \\
\hline Pengelolaan Air Minum dan & & & & & & & \\
\hline Makanan & & & & & & & 0,001 \\
\hline $\mathrm{Ya}$ & 117 & 43,3 & 153 & 56,7 & 270 & 95,4 & \\
\hline Tidak & 16 & 84,2 & 3 & 15,8 & 19 & 4,6 & \\
\hline Total & 133 & 46,0 & 156 & 56,0 & 289 & 100 & \\
\hline
\end{tabular}

Berdasarkan uji statistik diperoleh hasil nilai $p=0,000(p<0,05)$ artinya ada hubungan perilaku cuci tangan pakai sabun (CTPS) dengan kejadian stunting. Perilaku masyarakat yang dominan sudah menerapkan perilaku CTPS baik sebelum dan sesudah beraktivitas berdampak positif terhadap status gizi anak. Hal ini sejalan dengan hasil penelitian yang dilaksanakan di wilayah kelurahan Kampung Melayu DKI Jakarta tentang sanitasi lingkungan dimana perilaku cuci tangan pakai sabun termasuk didalamnya berhubungan dengan status gizi balita, gizi normal sebagian besar memiliki sanitasi lingkungan dengan kategori baik yaitu sebesar $100 \%$. Balita dengan status gizi stunting sebagian besar memiliki sanitasi lingkungan dengan kategori baik yaitu sebesar 68,4\%, namun balita dengan status gizi stunting sebesar 31,6\% memiliki sanitasi lingkungan dengan kategori tidak baik. Berdasarkan hasil uji statistik chi-square didapatkan $p$ value 0,000 dapat disimpulkan bahwa variabel independen yakni sanitasi lingkungan memiliki hubungan yang signifikan dengan kejadian stunting (Rahayu, 2019).

Penelitian tentang faktor - faktor yang dapat meningkatkan risiko stunting yang disebabkan oleh lingkungan rumah adalah kondisi tempat tinggal, penyediaan air bersih yang kurang dan kebersihan lingkungan yang tidak memadai yang dilaksanakan di Libya (Adel et al, 2009). Perilaku mencuci tangan setelah buang air besar dan sebelum memberi makan pada bayi berhubungan dengan kejadian stunting di Ethiopia (Kwami et al, 2019).

Beberapa penelitian tentang infeksi cacing ternyata menunjukkan bahwa anak usia sekolah merupakan golongan yang sering terkena infeksi cacing 
karena sering bermain dengan tanah. Infeksi cacing dapat menimbulkan kerugian zat gizi berupa kalori dan protein serta kehilangan darah. Selain dapat menghambat perkembangan fisik, kecerdasan dan produktifitas kerja, dapat juga menurunkan ketahanan tubuh sehingga mudah terkena penyakit (Renanti, 2015).

Penelitian formatif tentang perilaku kebersihan dan geophagy di kalangan bayi dan anak-anak kecil dan implikasi dari paparan terhadap bakteri tinja yang dilaksanakan di Distrik Shurugwi Provinsi Midlands, Zimbabwe, menunjukkan dari 250 kegiatan, ibu yang mencuci tangan sebanyak 109 kali (44\%) tetapi hanya menggunakan sabun tujuh kali (6\%). Para ibu mencuci tangan setelah menggunakan toilet, bersentuhan dengan kotoran hewan, atau mengganti popok. Dari 53 kesempatan, dari 17 kali (32\%) yang mencuci tangan namun yang menggunakan sabun hanya 4 kali (24\%) (Francis et al, 2013).

Perilaku masyarakat mencuci tangan tidak menggunakan air mengalir dan sabun disebabkan oleh beberapa faktor yaitu kebiasaan dan keadaan ekonomi. Kebanyakan alasan responden tidak menggunakan sabun saat cuci tangan adalah keterbatasan ekonomi untuk menyiapkan sabun untuk digunakan setiap selesai beraktifitas. Temuan ini sejalan dengan penelitian di Distrik Shurugwi Provinsi Midlands, Zimbabwe, yang menunjukkan bahwa faktor - faktor sosial ekonomi dan aksesibilitas atau penerimaan sabun dapat berperan dalam penggunaan sabun dan praktik kebersihan (Francis et al, 2013).

Tingkat pengamatan mencuci tangan dengan sabun setelah kontak dengan tinja $(7 \%)$ jauh lebih rendah daripada yang dilaporkan dalam penelitian di Bangladesh, yang didasarkan pada lima jam pengamatan terstruktur, dan melaporkan bahwa mencuci tangan dengan sabun dilakukan setelah perawatan orang dewasa, buang air besar (33\%) dan setelah buang air besar pengasuh dewasa dan membersihkan anak setelah membuang tinja (23\%), dan kurang dari setengah tingkat yang dilaporkan (17\%) dalam tinjauan komprehensif studi penelitian formatif yang dilakukan di 11 negara berpenghasilan rendah. Tingkat rendah yang sama dari mencuci tangan dengan sabun setelah kontak tinja dilaporkan di beberapa negara berpenghasilan rendah lainnya. Setengah dari pengasuh positif $E$. coli yang jarang mencuci tangan dengan sabun setelah kontak feses. Frekuensi kontaminasi tinja yang serupa pada tangan ibu dan anak juga dilaporkan di Tanzania (Amy et al, 2015).

\section{Hubungan Pengelolaan Air Minum dan Makanan Rumah Tangga dengan stunting}

Hasil analisis bivariat antara variabel pengelolaan air minum dan makanan dengan stunting ditunjukkan pada Tabel 4. Hasil analisis bivariat antara variabel pengelolaan air minum dan makanan dengan stunting diperoleh hasil $p$ value $=0,001$. Hasil penelitian tentang penggunaan air bersih dan makanan terhadap stunting menunjukkan bahwa dari 289 responden, yang sudah mengelolah air bersih dan makanannya sebanyak 270 orang diantaranya 117 orang $(43,3 \%)$ mengalami stunting dan sebanyak 153 orang $(56,7 \%)$ tidak mengalami stunting. Sedangkan responden yang belum mengelolah air bersih dan makanan sebanyak 19 orang diantaranya 16 orang $(84,2 \%)$ mengalami stunting dan 3 orang $(15,8 \%)$ tidak mengalami stunting. Berdasarkan uji statistik diperoleh nilai $p=0,001(p<0,05)$ artinya ada hubungan pengelolaan air minum dan makanan rumah tangga dengan stunting. Hasil penelitian ini sama dengan yang dilakkukan di pulau Sumatera (Sumatera Utara, Sumatera Selatan dan Lampung) menunjukkan bahwa ada hubungan antara keluarga yang menggunakan air bersih dengan kejadian stunting $(p=0,001 ;<0,05$ (Oktarina dan Sudiarti, 2014). 
Masyarakat melakukan kegiatan mengelola air minum dan makanan di rumah tangga untuk memperbaiki dan menjaga kualitas air dari sumber air yang akan digunakan untuk air minum, serta untuk menerapkan prinsip hygiene sanitasi pangan dalam proses pengelolaan makanan di rumah tangga. Pengelolaan air minum dan makanan rumah tangga (PAMM-RT) merupakan suatu proses pengolahan, penyimpanan, dan pemanfaatan air minum dan pengelolaan makanan yang aman di rumah tangga (Kemenkes, 2014).

Sebagian besar responden yang telah mengelolah air minum memperoleh sumber air bersih menggunakan jaringan perpipaan. Dari aspek kualitas fisik air bersih telah memenuhi syarat kesehatan. Selain menggunakan air minum yang memenuhi syarat kesehatan mereka juga menggunakan air bersih tersebut dalam mengolah makanan yang mereka konsumsi. Sekitar $76,8 \%$ responden yang telah menggunakan air bersih diperoleh melalui jaringan perpipaan.

Penelitian yang dilaksanakan di wilayah Klaten, Sikka dan Jayawijaya menunjukkan bahwa terdapat hubungan yang signifikan antara fasilitas sanitasi rumah tangga, pengolahan air rumah tangga dengan stunting. Prevalensi stunting secara signifikan lebih tinggi diantara anak - anak yang tinggal rumah tangga yang minum air yang tidak diolah dibandingkan dengan yang diolah $(38,2 \%$ dan $27,3 \%)$ (Harriet et al, 2016).

Hasil penelitian ini sejalan dengan penelitian yang dilakukan di India menemukan bahwa efek perlindungan dari ibu atau pengasuh yang melaporkan perilaku hygiene perorangan terhadap kejadian stunting meningkat saat mereka disertai dengan akses rumah tangga terhadap air melalui perpipaan. Sebuah meta analisis data dari 14 uji coba cluster secara acak yang dilakukan di 10 negara berpenghasilan rendah dan menengah menemukan manfaat kecil intervensi air, sanitasi dan hygene pada tinggi badan anak di bawah usia lima tahun. Fasilitas air sanitasi dan hygene yang rendah dan perilaku buruk dapat berdampak pada status gizi anak dengan menyebabkan diare, infeksi cacing usus atau penyakit enteropati. Infeksi dan kondisi ini secara langsung mempengaruhi status gizi melalui jalur hilangnya nafsu makan, kehilangan jaringan inang, pencernaan yang buruk atau malabsorpsi gizi, aktivasi kekebalan kronis dan tanggapan lain untuk infeksi yang mengalihkan penggunaan zat gizi dan energi, seperti demam (Jee et al, 2015). Hal ini diperkuat dengan teori yang menyatakan bahwa sanitasi air yang tidak baik akan berperan besar terhadap penyebaran penyakit menular (Sidhi dkk, 2016). Penelitian di Tikala, Manado menunjukkan ada hubungan bermakna antara stunting dengan angka kejadian diare (Taliwongso dkk, 2017).

\section{PENUTUP}

Diketahui hasil penelitian bahwa perilaku mencuci tangan pakai sabun dan mengelola air minum dan makanan berhubungan dengan kejadian stunting. Disarankan kiranya masyarakat membudayakan perilaku cuci tangan pakai sabun pada masyarakat terutama ibu rumah tangga yang memiliki baduta serta peningkatan akses air bersih kepada seluruh lapisan masyarakat.

\section{UCAPAN TERIMA KASIH}

Ucapan terimakasih kami haturkan kepada Direktur Politeknik Kesehatan Kemenkes Palu yang telah memberikan kesempatan untuk melaksanakan penelitian ini, Kepala Dinas Kesehatan Kota Palu, Kabupaten Banggai, Kabupaten Donggala dan Kabupaten Sigi beserta jajarannya yang telah mengizinkan kami untuk melaksanakan penelitian di wilayah kerjanya. 


\section{DAFTAR PUSTAKA}

Adel ET, Ibrahim B, Salah MM, Abdel MA, Olivier GPG. 2009. Risk Factors for Stunting among Under-Fives in Libya. Public Health Nutrition. 12(8): 1141-1149.

Amy JP, Jennifer D, Sarah PW, Helena MH, Daniel PK, Douglas M, Rachelle S, Joshua SC, Jessie L, Annalise B, Kirsten RA. 2015. Hands, Water, and Health: Fecal Contamination in Tanzanian Communities with Improved, non-Networked Water Supplies. Environmental science \& technology. 113.

Badan Pusat Statistik. 2018. Indikator Tujuan Pembangunan Berkelanjutan Indonesia. Jakarta: Badan Pusat Statistik.

Dirjen Kesmas Kemenkes RI. 2018. Buku saku Pemantauan status Gizi Provinsi Sulawesi Tengah 2017. Jakarta: Dirjen Kesmas Kemenkes RI

Francis MN, Jean HH, Mduduzi NNM, Florence M, Kuda M, Margaret G, Exevia M, Bernard C, Andrew JP, Valerie C, Kathyrn JB. 2013. Formative Research on Hygiene Behaviors and Geophagy among Infants and Young Children and Implications of Exposure to Fecal Bacteria. American Journal of Tropical Medicine and Hygiene. 89(4): 709-716.

Harriet T, Aidan AC, Susy KS. 2016. Determinants of Stunting in Indonesian Children: Evidence from a Cross-Sectional Survey Indicate a Prominent Role for the Water, Sanitation and Hygiene Sector in Stunting Reduction. BMC Public Health. 16(1): 1-11.

Jee HR, Aidan AC, Bhupendra B, Victor MA, Suzanne C. 2015. Household Sanitation and Personal Hygiene Practices are Associated with Child Stunting in Rural India: A Cross-Sectional Analysis of Surveys. BMJ Open. 5(2): 1 - 21.

Kemenkes RI. 2014. Modul Pelatihan wirausaha STBM Di Indonesia. Jakarta: Kemenkes RI.

Kwami CS, Samuel G, Hippolyte G, Monica L. 2019. Water, Sanitation, and Hygiene: Linkages with Stunting in Rural Ethiopia. International journal of environmental research and public health. 16(20). 1-7.

Lestari W, Margawati A, Rahfiludin Z. 2014. Faktor Risiko Stunting pada Anak Umur 6 - 24 Bulan di Kecamatan Penanggalan Kota Subulussalam Provinsi Aceh. Jurnal Gizi Indonesia. 3(1): 37-45.

Oktarina Z dan Sudiarti T. 2014. Faktor Risiko Stunting pada Balita (24-59 Bulan) Di Sumatera. Jurnal Gizi dan Pangan. 8(3): 177-180.

Rahayu B. 2019. Hubungan Karakteristik Balita, Orang Tua, Higiene dan Sanitasi Lingkungan terhadap Stunting pada Balita. Binawan Student Journal. 1(1): 22-27.

Renanti. 2015. Hubungan Infeksi Soil Transmitted Helminth dengan Status Gizi pada Murid SDN 29 Purus Padang. kesehatan andalas. 4(2): 353 - 412.

Sidhi A, Raharjo M, Dewanti N. 2016. Hubungan Kualitas Sanitasi Lingkungan dan Bakteriologis Air Bersih terhadap Kejadian Diare pada Balita Di Wilayah Kerja Puskesmas Adiwerna Kabupaten Tegal. Jurnal Kesehatan Masyarakat. 4(3): 665-676.

Taliwongso FC, Manoppo JIC, Umboh A. 2017. Hubungan Stunting dengan Angka Kejadian Diare pada Siswa Sekolah Dasar di Kecamatan Tikala Manado. e-Clinic. 5(2): 242 - 249.

WHO, UNICEF, USAID. 2015. Improving Nutrition Outcomes with Better Water, Sanitation and Hygiene: Practical Solutions for Policies and Programmes. WHO, UNICEF, USAID. https://apps.who.int/iris/handle/10665/ 193991. 